\title{
Brazilian Version of the Inventory of the Dimensions of Emerging Adulthood: Investigating the Current Transition to Adulthood
}

\author{
Luciana Dutra-Thomé ${ }^{1}$ \\ Federal University of Bahia, Salvador, BA, Brazil \\ Silvia Helena Koller \\ Department of Psychology, Federal University of Rio Grande do Sul, Porto Alegre, RS, Brazil \\ North-West University, Vanderbijlpark, South Africa
}

\begin{abstract}
The goal of the present study was to analyze the factor structure of the Inventory of Dimensions of Emerging Adulthood (IDEA) in Brazil, in order to use the measure in subsequent studies in the country, and to provide data for comparison of the measure factor structure in different countries. The sample included 547 individuals; residents in Porto Alegre (RS), from low and high SESs, ranging in age from 18 to 29 years old. Results pointed out that the inventory presented a different structure when compared with the original measure. For instance, the item "separating from parents" migrated from the dimension Identity Exploration to Self-focused, influenced by Brazilian cultural specificities. The inventory examined IDEA presented a new factor structure, associated with Brazilian context and the structure of the items on the original measure. In conclusion, the measure is a satisfactory tool of investigation of the emerging adulthood phenomenon in Brazil and Latin America.
\end{abstract}

Keywords: Transition to adulthood, emerging adulthood, assessment, psychometric properties, Brazilian context.

\section{Versão Brasileira do Inventário das Dimensões da Adultez Emergente: Investigando a Atual Transição Para a Vida Adulta}

\section{Resumo}

O objetivo do presente estudo foi de analisar a estrutura fatorial do Inventário de Dimensões da Adultez Emergente (IDEA) no Brasil, a fim de utilizar a medida em estudos subsequentes no país, e para fornecer dados para comparação da estrutura fatorial do instrumento em diferentes países. A amostra incluiu 547 indivíduos entre 18 e 29 anos, residentes em Porto Alegre (RS), de níveis socioeconômicos alto e baixo. Os resultados apontaram que o inventário apresentou uma estrutura diferente no Brasil quando comparado com a medida original. Por exemplo, o item "separar-se dos pais" migrou da dimensão "Exploração da Identidade" para a dimensão "Foco em si mesmo", fato influenciado por especificidades culturais brasileiras. O inventário examinado apresentou uma nova estrutura fatorial, associada com o contexto brasileiro e com características específicas da distribuição dos itens na estrutura original. Por

Mailing address: Instituto de Psicologia, Rua Aristides Novis, 197, Estrada de São Lázaro, Salvador, BA, Brazil 40210-730. Phone: 3283-6437; Fax: 3283-6437. E-mail: lucianaduth@gmail.com and silvia.koller@ gmail.com

Apoio financeiro: Coordenação de Aperfeiçoamento de Pessoal de Nível Superior (CAPES) e Conselho Nacional de Desenvolvimento Científico e Tecnológico (CNPq). 
fim, conclui-se que a medida pode ser usada satisfatoriamente como uma ferramenta de investigação do fenômeno adultez emergente no Brasil e na América Latina.

Palavras-chave: Transição para a vida adulta, adultez emergente, avaliação, propriedades psicométricas, contexto brasileiro.

\section{Versión Brasileña del Inventario de las Dimensiones de la Adultez Emergente: Investigación de la Actual Transición para la Vida Adulta}

\section{Resumen}

El objetivo de este estudio fue examinar la estructura factorial del Inventario de las dimensiones de la adultez emergente (IDEA) en Brasil, con el fin de utilizar la medida en estudios posteriores en el país, y para proporcionar datos para la comparación de la estructura factorial del instrumento en diferentes países. La muestra incluyó 547 individuos entre 18 y 29 años que viven en Porto Alegre (RS), niveles socioeconómicos alto y bajo. Los resultados mostraron que el inventario tenía una estructura diferente en Brasil cuando se compara con la medida original. Por ejemplo, el ítem «separarse de sus padres» emigró de la dimensión «Exploración de la identidad» para la medida «centrarse en sí mismo» y hecho de la influencia de las especificidades culturales de Brasil. El inventario examinado presenta una nueva estructura factorial, asociado con el contexto y las características específicas de brasileños y de la distribución de los elementos de la estructura original. Por último, se concluye que la medida puede utilizarse satisfactoriamente como una herramienta de investigación de la adultez emergente en Brasil y América Latina.

Palabras clave: Transición a la vida adulta, adultez emergente, evaluación, propiedades psicometricas, contexto brasileño.

The definitions of developmental stages are important references to understand the processes of continuities and changes of human beings over their life cycle. Developmental stages provide information regarding what to expect of human development in terms of biological, psychological and social processes.

In the field of Psychology, infancy and adolescence became developmental stages emphasized in research, frequent known by a general public. Infancy and adolescence present biological, psychological, and social markers. Moreover, children and adolescents present clearer institutional ties, namely family and school. When individuals reach adulthood, their developmental processes do not present crucial biological markers, and individuals' characteristics are more attached to social aspects.

The Theory of Psychosocial Development proposed by Erikson $(1950,1968)$ is the most consolidated perspective to understand the adult's development in the field of Developmental Psychology. Nevertheless, over the decades, the stages proposed by Erikson have changed, associated with historical and social influences, such as the invention of the birth control pill; the change on sexual morality standards after the sexual revolution of the 1960s and early 1970s; and the change in the roles of women. Young individuals' period of social moratorium became longer, and they live an extended process of identity formation (Demuth \& Keller, 2011). Consequently, there is a new dynamic of transition to adulthood, particularly observed in industrialized and post-industrialized societies. This new dynamic led to the proposal of a new perspective in the field of development psychology which culminated in the suggestion of a new developmental stage, named emerging adulthood (EA; Arnett 2000, 2011). EA refers to the extension of the transition to adulthood, characterized by longer investment in higher 
education and training, pre-marital sexual relations, cohabiting, and postponement of marriage and parenthood until the late twenties or early thirties (Arnett, 2007).

Evidence of EA exists, based on demographical, subjective, and identity exploration topics (Arnett, 2000) that leads to the definition of characteristics that clarifies the specificity of the life stage. The five EA key features are: (a) "Identity Exploration", because individuals are open to try different experiences in love relationships, job opportunities, education, and travelling. The openness to explore diverse fields is associated with the feature; (b) "Self-focus", which highlights young individuals' flexibility for choosing on their own, considering most of them have not constituted family, do not have kids, and a steady job. Due to the instability of their lives, emerging adults' present feelings of (c) "Negativity-instability" resulted of, for example, plans they establish that do not work. The feature (d) "Experimentation/Possibilities" refers to the fact that emerging adults are optimistic in relation to the future, since they believe they will reach the live they predict. Finally, in the base of all features, the one named (f) "Feeling-in-between" demarks the main subjective marker of EA, referring to the fact that emerging adults do not feel entirely adults nor adolescents, merging characteristics of both developmental stages.

Based on these five key features, Reifman, Arnett, and Colwell (2007) developed the Inventory of the Dimensions of Emerging Adulthood (IDEA). Currently, this is the only measure applied in different countries to study EA's key features (Atak \& Çok, 2008; Facio, Resett, Micocci, \& Mistrorigo, 2007; Fierro Arias \& Moreno Hernandez, 2007; Macek, Bejcek, \& Vanickova, 2007). A sixth feature named "Other-focus" was included in the measure and proposed as opposite to the feature "Self-focus". The Other-focus is considered a counterpart of the feature Self-focused because it is associated with responsibility for others, and commitment to others (Reifman et al., 2007). The authors expected that individuals older than the presumed EA age range would present more "other-focused" experiences than those in the EA range.

The IDEA is composed of a referential statement "This period in your life is..." followed by 31 items (e.g. "time of confusion", "time of being not sure whether you have reached full adulthood"). Participants indicated the degree to which they agreed or disagreed the phrase described this period in their life: (1) Strongly Disagree, (2) Somewhat Disagree, (3) Somewhat Agree, (4) Strongly Agree.

The 31 original IDEA items were subjected to a Principal Components Factor Analysis, followed by Varimax rotation (Reifman et al., 2007). Six subscales were identified: Identity exploration (items 12, 23, 24, 25, 26, 27, and 28); Experimentation/possibilities (items 1, 2, 4, 16, and 21); Negativity/instability (items 3, 6, 8, 9, 11, 17, and 20); Self-focused (items 5, 7, 10, 15, 19, and 22); Feeling in-between (items 29, 30, and 31); and Other-focused (items 13, 14, and 18). For all subscales, the higher scores represent the higher sum of the construct of EA. Originally, the IDEA possessed a maximum score of 124 and minimum score of 31 . The reliability coefficients for the subscales ranged between .70 and .80 . Test-retest reliability correlations, a month after the first application, presented scores ranged between .64 and .76, with the exception of the Feeling in-between subscale (.73; Reifman et al., 2007; see Table 1).

Table 1

Subscales Reliability of the IDEA Measure

\begin{tabular}{lll}
\hline Items & Subscale & $\alpha$ \\
\hline $12,23,24,25,26,27,28$ & $\begin{array}{l}\text { Identity exploration } \\
\text { Experimentation/ }\end{array}$ & .85 \\
$1,2,4,16,21$ & $\begin{array}{l}\text { possibilities } \\
\text { Negativity/ }\end{array}$ & .82 \\
$3,6,8,9,11,17,20$ & $\begin{array}{l}\text { instability } \\
\text { Feeling in-between }\end{array}$ & .73 \\
$29,30,31$ & Self-focused & .70 \\
$5,7,10,15,19,22$ & Other-focused & .80 \\
$13,14,18$ & &
\end{tabular}

Note. Total scale alpha with an North-American sample of 243 participants aged 18 through 70 and over $(\alpha=.82)$. 


\section{IDEA in Other Countries}

EA changes from culture to culture and varies even among subcultures within a country. Therefore, it is important to consider contextual aspects affecting IDEA's reliability and validity while a measure applied in studies all over the world (Atak \& Çok, 2008).

Fierro Arias and Moreno Hernandez (2007) presented an inventory based on IDEA (Reifman et al., 2007) and Arnett's EA theoretical proposal to 720 Mexican and Spanish males and females. They were aged 16 to 34 years and their educational level ranged from high school to postgraduate work. The adaptation proposed a new structure to the original inventory. A Principal Components Factor Analysis with Varimax rotation was conducted, revealing seven subscales related to transition to adulthood: (a) Adulthood Postponement, (b) Instability, (c) Autonomy, (d) Explorations, (e) Vision of Future and Possibilities, (f) Worries, and (g) Identity Moratorium. The reliability test for the whole EA scale was .68 (Fierro Arias \& Moreno Hernandez, 2007). The authors created new items and proposed different dimensions. They identified that open possibilities, visualized future and sensations of worry were independent of age. From the group between 16- to 17-year-olds forward, there was a tendency towards decreasing levels of instability and adulthood postponement, and increasing levels of autonomy. For the factor Explorations, there was a stability of trend, what may indicate this is not a specific characteristic of EA. Authors highlighted the importance of expanding the research to younger and older groups, in order to investigate more consistently whether these factors are particular experiences of people in their 20s. Moreover, the findings revealed that both Mexicans and Spaniards of all ages experienced "feeling in between" and were not sure about their adolescence's end. They doubted that they had fully reached adulthood (Fierro Arias \& Moreno Hernandez, 2007).

In Turkey, researchers adapted the IDEA (Atak \& Çok, 2008) using the Principle Components Analysis followed by Varimax rotation. They found a three factors solution, composed of subscales named Negativity/instability, Identity explorations/feeling in-between, and Experimentation/self-focused. The final Turkish scale was composed of 23 items. Eleven items were removed in the Turkish version of the IDEA, because their factor loading were low. The testretest method indicated the Turkish version of the instrument was reliable and valid (Atak \& Çok, 2008).

Macek et al. (2007) developed a questionnaire for the Czech Republic based on the IDEA. They added two new dimensions to the original instrument, namely Determination of commitments and Personal responsibility, formulated using items more relevant to Czech cultural environment. The final version of the questionnaire consisted of 31 items. In order to analyze the new structure of the questionnaire, they ran a Principle Components Analysis followed by Varimax rotation. A six-factor structure was identified, which contained new dimensions, such as "Clarity of values", associated with a clear view of the person's values and plans, and "Diffuse orientation", associated with reluctance to accept the consequences of one's own actions (Macek et al., 2007).

Studies using IDEA indicated that the factor structure of the measure varies in different countries, which indicates the importance of analyzing IDEA's properties in each context. In Brazil, investigations about entering into adulthood (Borges \& Magalhães, 2009; Camarano, 2006; Camarano, Mello, Pasinato, \& Kanso, 2004) were not conducted based on the EA theory. In view of investigating EA in Brazil and contributing to the investigation of EA in Latin America, it is important to adapt the instrument to the Brazilian context.

Considering that, the study goal was to analyze the psychometric properties of IDEA in a Brazilian sample. This step of analysis is part of a broader study, focusing on investigating the EA phenomenon in a Southern Brazilian sample. The measure may be used as a tool of investigation of EA in Brazil, and as reference to compare the measure factor structure in different countries. 


\section{Method}

\section{Sample}

The sample included 547 Southern Brazilians; residents in Porto Alegre, Rio Grande do Sul State, between 18 and 29 years old $(M d=22$ years; IQR $\left.{ }^{2}=19-26\right), 196(35.8 \%)$ males, and $351(64.2 \%)$ females, of low $(n=194,35.5 \%)$ and high SES $(n=353,64.5 \%)$. To include young individuals from differing SESs, different institutions were selected in the process of recruiting participants: (a) two technology courses; (b) three universities; (c) two courses focused on preparing students from low SES to the university entrance exam; and (d) two schools that work with young individuals and adults with limited or no previous education (e.g., people with writing and reading difficulties and with solving basic math problems). The study questionnaire and instruments were digitalized and applied by two methods: online (i.e., the participant was invited by e-mail to access an external website where the instruments were available) and in-person (i.e., the participant completed the instruments in a lab with one researcher present). In both cases, the instruments were self-administered.

\section{Ethical Considerations}

The research was approved by the Research Ethics Committee of the Federal University of Rio Grande do Sul (Protocol Number 2011014). All participants signed the Consent Form (Resolutions $n^{\circ} 196 / 1996$ of the National Health Council, and $n^{\circ} 016 / 2000$ of the Brazilian Federal Council of psychology).

\section{Back Translation}

The first step was an independent translation into Portuguese by the first author. The version was reviewed by two bilingual judges, who had no knowledge about the instrument. They compared the original version in English with the version translated into Portuguese, and their suggestions for change were made. The revised version in Brazilian Portuguese was then

2 Interquartile range. back translated into English by a researcher in U.S. who is fluent in both English and Brazilian Portuguese. After that, the same version was reviewed and back translated into English by two bilingual judges, both fluent speakers in Brazilian Portuguese and English. The back translated version was similar to the original.

After the back translation process, members of the Youth Research Group: Resilience and Vulnerability, from the Brazilian Post-Graduate and research National Association (ANPEPP) analyzed the instrument in order to identify possible items that should be added to the Brazilian version. Based on their suggestions, the items "time to prepare yourself for adulthood" and "time of professional decisions" were included. The first item aimed to access in which extent becoming an adult configures a societal expectation in relation to young people. The second item aimed to consider topics related to profession and career, which are central for young Brazilians.

The ANPEPP group suggested a replacement of the translation into Portuguese of the item 13 from the original instrument ("time of settling down", translated into Portuguese as "tempo de se estabelecer"). They proposed a translation into "tempo de consolidar projetos de vida", equivalent in English to "time to consolidate life projects". The new translation would avoid inadequate interpretations considering the term "settling down" does not have an equivalent in Portuguese.

\section{Results}

Confirmatory Factor Analysis (CFA) was used to evaluate whether the original structure of the IDEA fits to the Brazilian context. To take into account the categorical nature of the scale items, the Weighted Least Square Mean Variance (WLSMV) estimation method was employed in the Mplus software. For fit indices, the Chi-Square $\left(\chi^{2}\right)$, Comparative Fit Index (CFI), Tucker-Lewis Index (TLI), Root Mean Square Error of Approximation with $90 \%$ Confidence Interval (RMSEA - 90\% CI), and Weighted Root Mean Square Residual (WRMR) were cal- 
culated. A non-significant Chi-Square $(p>.05)$ represents a good fit. Values of the CFI and TLI above .90 or close to .95 represent a good fit. Values of the RMSEA close to or below .05 represent a good fit, and below .08 represent an acceptable fit. Values of the WRMR below .60 represent a good fit (Yu, 2002).

The CFA results showed that the original model of the IDEA did not fit well in the Brazilian sample $\left(\chi^{2}(465)=637, p<.001 ; \mathrm{CFI}=\right.$ $.816, \mathrm{TLI}=.796, \mathrm{RMSEA}=.069(\mathrm{CI} 90 \%)[.065$ $-.073]$, WRMR $=1.77$ ). Because of that, an Exploratory Factor Analysis (EFA) was performed on the 33 self-report IDEA items (31 original plus the two Brazilian items), considering the importance of evaluating the factorial structure of the measure in the Brazilian sample. Although the original instrument was developed with a Principal Component Analysis (PCA) with Varimax rotation, the present study used Principal Axis Factoring (PAF) extraction method with Oblimin rotation. PAF is considered more robust (Costello \& Jason, 2005), and possibly will provide more accurate results. The PAF extraction method with Oblimin rotation allows correlations between factors and deals with only the common variance, while the PCA analyses the total variance (Costello \& Jason, 2005).
The adequacy of the sample for this procedure was assessed using the Kaiser-Meyer-Olkin (KMO) and Bartlett's sphericity test. Reliability was assessed using Cronbach's alpha index (Cronbach, 1951).

The number of factors extracted was based on the following criteria: (a) instrument theoretical background; (b) Kaiser (1960) criteria (the maximum number of factors extracted must have eigenvalues higher than one); (c) Scree plot, a graphic showing the eigenvalues on the $\mathrm{y}$-axis and the number of factors on the $\mathrm{x}$-axis in a downward curve. The point where the curve slope is leveling off (the "elbow) indicates the number of factors to retain; and (d) parallel analysis, which compares the eigenvalues empirically found with random eigenvalues (Hayton, Allen, \& Scarpello, 2004; Horn, 1965).

Using PAF (Barlett's test of sphericity = $4536,535, d f=528 ; p<.0001 ; \mathrm{KMO}=.82)$, eight factors were extracted (i.e., eigenvalue $>1$ ). These eight factors accounted for $46.8 \%$ of the total variance. Communalities of the 33 items presented a range of .191 (item 23) to .599 (item 30). According to the scree-plot test, eight factors also emerged. The parallel analysis (see Figure 1) suggested that a six factor solution was most representative of the data.

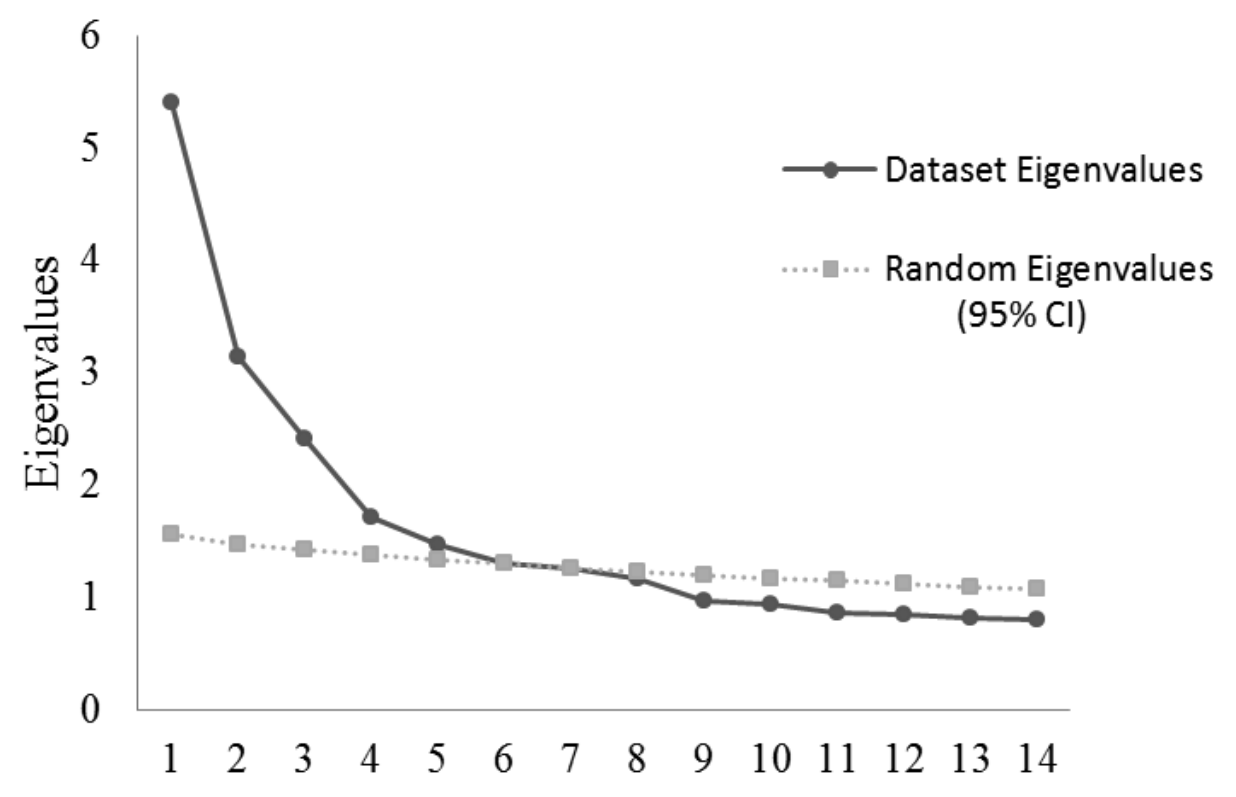

Factor Number

Figure 1. Scree Plot of the empirical eigenvalues and random eigenvalues of the IDEA. 
Built upon the theoretical structure of the original study (Reifman et al., 2007) and the parallel analysis, a PAF was conducted imposing a six factor structure on the solution. However, although the number of factors was equal, they presented a different composition, when compared to the original instrument, especially in relation to Factor 2 (Self-focused).

Six items loaded significantly (i.e., factor loadings $>.30$ ) on Factor 1 (Identity Exploration; eigenvalue $=5.40$ ), and accounted for $16.3 \%$ of the variance; 10 items loaded significantly on Factor 2 (Self-focused; eigenvalue $=3.40$ ), and accounted for $9.5 \%$ of the variance; Seven items loaded significantly on Factor 3 (Negativity/Instability; eigenvalue $=2.41$ ), and accounted for 7.3\%; Four items loaded significantly on Factor 4 (Experimentation/Possibilities; eigenvalue $=$ 1.70 ), and accounted for $5.2 \%$ of the variance; Four items loaded significantly Factor 5 (Feeling in-between; eigenvalue $=1.5$ ), and accounted for $4.5 \%$ of the variance; Two items loaded significantly Factor 6 (Other-focused; eigenvalue = 1.30 ), and accounted for $4 \%$ of the variance.

There were differences and similarities in relation to the original measure. The items "Separating from parents" (item 23) and "Planning for the future" (item 25), loaded on the factor "Self-focused" but not on the Factor "Identity exploration". The items "Optimism" (item 10), "Open choices" (item 16), "Trying out new things" (item 21) presented factor loadings lower than .30 and were removed from the subsequent analysis. The item "Settling down" (item 13) pertained to the factor "Other-focused" in the original scale, and loaded on the factor "Selffocused" in the Brazilian sample. The Brazilian items added were "Time to prepare yourself to adulthood" (item 32) and "Time of professional decisions" (item 33). The first one loaded on the "Feeling-in-between", and the second one was removed due to a factor loading lower than 30 . Subsequently, an EFA was reconducted and the item "Planning for the future" (item 25) moved back to the Factor "Identity exploration".

The new structure of IDEA in the Brazilian sample presented the following characteristics: 29 items divided into the following subscales (a)
Identity Exploration (items 12, 24, 26, 27, and 28); (b) Experimentation/Possibilities (items 1, 2, 4); (c) Negativity/Instability (items 3, 6, 8, 9, 11, 17, and 20); (d) Self-Focused (items 5, 7, 13, 15, 19, 22, 23 and 25); (e) Feeling In-Between (items 29, 30, 31, and 32), and (f) Other-Focused (items 14, and 18). For all subscales, the higher scores represent the higher sum of the construct of EA. The original reliability scale (Cronbach's alpha) was 0.81. In Brazil, Cronbach's alpha coefficients for the six subscales ranged from .61 to .79. The full-scale Cronbach's alpha reliability was .80 (i.e., 29 items, see Table 2).

\section{Discussion}

The investigation of the factorial structure of IDEA in Brazil brought a significant contribution for researchers interested in studying the process of transition to adulthood in the country. Investigators may use the measure, which was adapted to Brazilian contextual characteristics.

In the Brazilian sample, the item "Separating from parents" (item 23) loaded on the Factor Self-focused but not on the Factor Identity exploration, like in the original measure. In Turkey, the item "Separating from parents" also loaded on a different Factor, which they named "Selffocused/Experimentation" (Atak \& Çok, 2008). It is possible to analyze this new structure in two different ways. First, the factor Identity exploration contains items related to psychological selfexploration, such as "Finding out who you are" (item 12), "Defining yourself" (item 24), "Seeking a sense of meaning" (item 26), "Deciding on your own beliefs and values" (item 27), and "Learning to think for yourself" (item 28). The item "separating from parents" (item 23) differ from this logic, since they may represent self-focused attitudes and are not necessarily associated with psychological self-exploration. "Separating from parents" (item 23) demands the individual to focus on himself/herself in order to have the opportunity of exploring identity.

The Brazilian culture is characterized by giving high importance to family, similarly to other Latin and Asian countries; and by catholic influence (Facio \& Micocci, 2003; Facio et al., 
Table 2

Exploratory Factor Analysis of the 29-item IDEA

\begin{tabular}{|c|c|c|c|c|c|c|c|c|}
\hline \multirow{2}{*}{ Items } & \multirow{2}{*}{$\begin{array}{l}\text { Original Items } \\
\text { Time of... }\end{array}$} & \multirow{2}{*}{$\begin{array}{r}\text { Brazilian Portuguese Items } \\
\text { Tempo de... }\end{array}$} & \multicolumn{6}{|c|}{ Factor loadings } \\
\hline & & & IE & Self & Neg. & Pos. & IB & Other \\
\hline 26 & $\begin{array}{l}\text { seeking a sense } \\
\text { of meaning? }\end{array}$ & $\begin{array}{r}\text { buscar um senso } \\
\text { de significado? }\end{array}$ & $.74^{*}$ & -.03 & .01 & .09 & -.01 & -.02 \\
\hline 27 & $\begin{array}{l}\text { deciding on your own } \\
\text { beliefs and values? }\end{array}$ & $\begin{array}{r}\text { decidir sobre suas próprias } \\
\text { crenças e valores? }\end{array}$ & $.71^{*}$ & -.06 & -.03 & .01 & .16 & -.08 \\
\hline 24 & defining yourself? & definir a si mesmo? & $.61^{*}$ & .17 & .11 & -.02 & -.04 & .01 \\
\hline 28 & $\begin{array}{l}\text { learning to think for } \\
\text { yourself? }\end{array}$ & $\begin{array}{r}\text { aprender a pensar } \\
\text { por si mesmo? }\end{array}$ & $.55^{*}$ & -.09 & -.06 & .00 & .31 & -.06 \\
\hline 12 & finding out who you are? & descobrir quem você é? & $.41^{*}$ & .00 & .08 & .15 & .14 & -.01 \\
\hline 15 & independence? & independência? & -.07 & $.63^{*}$ & -.04 & -.07 & -.03 & -.16 \\
\hline 22 & focusing on yourself? & focar em si mesmo? & .16 & $.42 *$ & .15 & .04 & .07 & .26 \\
\hline 13 & settling down? & $\begin{array}{r}\text { consolidar projetos } \\
\text { de vida? }\end{array}$ & .07 & $.41 *$ & -.12 & .01 & -.01 & -.21 \\
\hline 19 & self-sufficiency? & auto-suficiência? & -.05 & $.39 *$ & .07 & -.01 & -.08 & -.18 \\
\hline 5 & personal freedom? & liberdade pessoal? & -.16 & $.38 *$ & -.06 & .21 & .12 & .04 \\
\hline 25 & planning for the future? & planejar para o futuro? & .26 & $.33^{*}$ & -.05 & .03 & -.02 & .09 \\
\hline 7 & $\begin{array}{l}\text { responsibility for } \\
\text { yourself? }\end{array}$ & $\begin{array}{r}\text { se responsabilizar por si } \\
\text { mesmo? }\end{array}$ & .05 & $.33^{*}$ & -.02 & .07 & -.07 & -.11 \\
\hline 23 & separating from parents? & se separar dos pais? & .17 & $.30^{*}$ & .18 & -.05 & -.14 & .07 \\
\hline 9 & instability? & instabilidade? & -.02 & -.04 & $.64 *$ & .05 & .03 & .11 \\
\hline 3 & confusion? & confusão? & .01 & -.09 & $.60^{*}$ & .20 & .10 & .11 \\
\hline 17 & unpredictability? & imprevisibilidade? & -.07 & .08 & $.59 *$ & .10 & .10 & -.04 \\
\hline 8 & feeling stressed out? & se sentir estressado? & .10 & .01 & $.53 *$ & -.07 & -.05 & -.13 \\
\hline 6 & feeling restricted? & se sentir limitado? & -.02 & -.08 & $.45^{*}$ & -.07 & .06 & -.00 \\
\hline 20 & many worries? & muitas preocupações? & .04 & .07 & $.44^{*}$ & -.14 & .03 & -.17 \\
\hline 11 & high pressure? & muita pressão? & .10 & .03 & $.43^{*}$ & .09 & -.05 & -.13 \\
\hline 2 & exploration? & descobertas? & .14 & -.14 & .08 & $.72 *$ & -.05 & -.00 \\
\hline 1 & many possibilities? & muitas possibilidades? & .03 & .05 & -.07 & $.55^{*}$ & -.14 & -.01 \\
\hline 4 & experimentation? & experimentação? & -.05 & .03 & .16 & $.54^{*}$ & .15 & -.06 \\
\hline 29 & $\begin{array}{l}\text { feeling adult in some } \\
\text { ways but not others? }\end{array}$ & $\begin{array}{r}\text { se sentir adulto em } \\
\text { alguns aspectos mas } \\
\text { não em outros? }\end{array}$ & -.01 & -.04 & .06 & .03 & $.73 *$ & .02 \\
\hline 30 & $\begin{array}{l}\text { gradually becoming } \\
\text { an adult? }\end{array}$ & $\begin{array}{r}\text { gradualmente se tornar } \\
\text { um adulto? }\end{array}$ & .10 & .00 & -.02 & -.04 & $.70^{*}$ & .03 \\
\hline 32 & $\begin{array}{l}\text { prepare yourself } \\
\text { to adulthood? }\end{array}$ & $\begin{array}{l}\text { se preparar para } \\
\text { a vida adulta? }\end{array}$ & .010 & .08 & .01 & -.02 & $.62 *$ & .02 \\
\hline 31 & $\begin{array}{l}\text { being not sure whether } \\
\text { you have reached full } \\
\text { adulthood? }\end{array}$ & $\begin{array}{r}\text { não ter certeza se você } \\
\text { atingiu completamente } \\
\text { a vida adulta? }\end{array}$ & .08 & -.06 & .21 & -.08 & $.57^{*}$ & .00 \\
\hline
\end{tabular}



the Current Transition to Adulthood.

\begin{tabular}{|c|c|c|c|c|c|c|c|c|}
\hline 14 & responsibility for others? & $\begin{array}{r}\text { responsabilidade } \\
\text { por outros? }\end{array}$ & .04 & .08 & .09 & -.02 & .01 & $-.63 *$ \\
\hline 18 & commitments to others? & $\begin{array}{c}\text { compromissos } \\
\text { com os outros? }\end{array}$ & .04 & .03 & .06 & .10 & -.03 & $-.62 *$ \\
\hline
\end{tabular}

Factors

Factor indexes

I.E. Self Neg. Pos. I.B. Other

Eigenvalues

Coefficient alphas $(\alpha)$

Means $(S D)$

Total explained variance $(\%)$

\begin{tabular}{rrrrrr}
5.40 & 3.14 & 2.41 & 1.71 & 1.48 & 1.31 \\
.79 & .62 & .74 & .61 & .78 & .62 \\
& & & & & \\
3.29 & 3.30 & 2.95 & 3.46 & 3.15 & 2.81 \\
$(.63)$ & $(3.86)$ & $(.54)$ & $(.50)$ & $(.71)$ & $(.77)$ \\
& \multicolumn{6}{c}{$46 \%$} \\
\end{tabular}

Note. IE $=$ Identity Exploration, Self $=$ Self-focused, Neg. $=$ Negativity, Poss. $=$ Experimentation $/$ Possibilities, IB = In-between, Other = Other-focused; Extraction method: Principal axis factoring; Rotation method: Oblimin; $S D=$ standard deviation.

*Significant factor loadings (.30 cut-off point).

${ }^{a}$ Explained variance not shown for each factor due to their possible correlation.

2007; Fuligni, 2007), which may lead individuals to be other-focused. Considering that, "separating from parents" (item 23) and "planning for the future" (item 25) may be associated with a selfcentered attitude, meaning the person is definitely in progress to build his/her own life. Different from U.S., in Brazil people are not necessarily expected to leave the parental home to study, which may influence the strong tie they establish with their family (Facio \& Micocci, 2003; Facio et al., 2007; Fuligni, 2007), so they prolong their staying at home (Henriques, Jablonski, \& FeresCarneiro, 2004; Veiga, 1998). This also seems to hold true in Argentina, where young individuals did not consider EA as the age for leaving home (Facio et al., 2007). North Americans usually leave home to start the university or simply to be independent, and it is expected they move out of home earlier. However, recently the residential status in U.S. has been changing and it is possible for individuals to come back home after finishing college (Arnett, 2000).

The item "separating from parents" (item 23) may also be associated with reaching autonomy and being able to support yourself, emotionally and financially. However, contextual problems (e.g., unemployment) make it difficult for young individuals to attain complete auton- omy. In Spain, high mean scores of the dimensions Instability and Moratorium reflected an influence of Mediterranean pattern of transition, associated with staying longer at parents' home and having difficulties to find a long-term employment (Fierro Arias \& Moreno Hernandez, 2007).

The item "Optimism" (item 10) presented factor loading lower than .30 , both in the Brazilian and the Turkish IDEA version (Atak \& Çok, 2008), and was removed from the analysis. The dimension Experimentation/Possibilities presented a different structure in Turkey, where young individuals are expected to be supported by family, institutions, and peers in their decisions (Atak \& Çok, 2008). They tend not to make independent decisions, what would explain the reason why the dimensions Selffocused and Experimentation were combined (Atak \& Çok, 2008). In Brazil, the subscale Experimentation/Possibilities also presented a different structure, and the items "Open choices" (item 16) and "Trying out new things" (item 21) migrated to the Factor Self-focused, and did not load significantly. Consequently, the Factor Experimentation/Possibilities was composed of the items "Many possibilities" (item 1), "Exploration" (item 2), and "Experimentation" (item 4). 
The items "Open choices" (item 16) and "Trying out new things" (item 21) did not load significantly in the Brazilian sample, which may reflect contextual specificities. Young individuals in Brazil, especially in low SES contexts, may have less opportunities of exploring different options of choices when compared to countries with higher economic stability, particularly because they assume adult roles earlier (Arnett, 2011; Barros \& Santos, 1996; Campos \& Francischini, 2003; Guimarães \& Romanelli, 2002; Marques, Neves, \& Carvalho, 2002; Sarti, 1996).

"Settling down" (item 13) pertained to the Factor "Other-focused" on the original scale, but loaded on the factor "Self-focused" in Brazil. It may reflect two aspects: (a) a problem of translation of the item because there is not an equivalent term in Brazilian Portuguese; (b) that the process of settling down does not explicitly relate to commitments to other people. Settling down also requires the person to have a clear idea of his/her personal goals. Defining personal plans may be a decision made alone, despite the fact that it possibly includes commitment to others (e.g., kids and stable job). It is also possible to consider Self-focused and Other-focused dimensions as a unit of opposites in Brazil. Commitment to family and work is associated with focusing on others, and/or requires individuals to be aware of what they want personally, which is a more self-focused attitude. For instance, a young man could be investing on professional training in order to get a better job position and, consequently be able to provide his family better conditions of living. In this case, a Self-focused would relate to an Other-focused goal.

In Turkey, authors removed the dimension Other-focused because items presented factor loadings lower than .30. They understood this result as related to the collectivistic values of their culture, present during the whole life cycle, not specifically during EA (Atak \& Çok, 2008).

The Brazilian items added were "Time to prepare yourself to adulthood" (item 32) and "Time of professional decisions" (item 33). The first one loaded on the Factor Feeling-in-between, which converged to EA theory, because the process of preparing yourself to adulthood leads individuals to feel ambivalent (Arnett, 2000). The second one was removed due to factor loading lower than .30. Most of young Brazilians define a profession to invest by their 17-18 years, when they choose which course they are going to attend at University (Bardagi, Lassance, \& Paradiso, 2003; Ramos \& Lima, 1996; Sparta, Bardagi, \& Andrade, 2005). Low SES participants tend to start working earlier (Arnett, 2011; Barros \& Santos, 1996; Campos \& Francischini, 2003; Guimarães \& Romanelli, 2002; Marques et al., 2002; Sarti, 1996). Participants may have understood that a professional choice in their personal life happened before in Brazil, and did not associate "Time of professional decisions" with a gradual transition to adulthood.

\section{Conclusion}

The results reflected the new IDEA structure in the Southern-Brazilian sample, and the necessity of reviewing the original measure. The original items of the Identity Exploration subscale may be better adjusted if all gathered in the same factor, because some items representing the dimension Identity Exploration (Arnett, 2000, 2004, 2011) were also present in the dimensions Self-focused and Experimentation/Possibilities (e.g. "time of personal freedom", and "experimentation", respectively), what might weaken IDEA's validity.

The Factor Experimentation/Possibilities describes an optimistic view of young individuals. No matter how their current life is, they always believe they will reach the life they envision (Arnett, 2000, 2004, 2011). This Factor was originally composed of items "Many possibilities" (item 1), "Exploration" (item 2), "Experimentation" (item 4), "Open choices" (item 16), and "Trying out new things" (item 21). In the original instrument, the item "Optimism" (item 10) pertained to the category Self-focused. "Optimism" (item 10) migrated to the category Experimentation/Possibilities in the Brazilian sample. Considering the original scale, it may be pertinent to move the item "Optimism" to the Factor Experimentation/Possibilities, due to 
its original definition. In Brazil, the item "Optimism" presented factor loading lower than .30, and thus removed from the analysis. It may indicate that Experimentation/Possibilities in Brazil was more associated with experimenting diverse experiences, than with an optimistic view of the future.

For future studies, researchers using the IDEA should consider the possibility of maintaining all IDEA's original items, allowing for future comparisons between samples from different countries. And also, that the original IDEA scale dates from 2007. Since then, social and economic aspects influenced the process of transition to adulthood in different countries (e.g. economic crisis of 2007; Pochmann, 2009) what may affect the structure of the measure. Finally, results found in the Brazilian sample may serve as reference point to improve the measure, when used in different countries and even in other Brazilian regions.

\section{References}

Arnett, J. J. (2000). Emerging adulthood: A theory of development from the late teens through the twenties. American Psychologist, 55, 469-480. doi:10.1037/0003-066X.55.5.469

Arnett, J. J. (2004). Emerging adulthood: The winding road from the late teens through the twenties. New York: Oxford University Press.

Arnett, J. J. (2007). Emerging adulthood: What is it, and what is it good for? Child Development Perspectives, 1, 68-73. doi:10.1111/j.17508606.2007.00016.x

Arnett, J. J. (2011). Emerging adulthood(s): The cultural psychology of a new life stage. In J. A. Lene (Ed.), Bridging cultural and developmental approaches to psychology: New synthesis in theory, research, and theory (pp. 255-275). Oxford, UK: University Press.

Atak, H., \& Çok, F. (2008). The Turkish version of Inventory of the Dimensions of Emerging Adulthood (The IDEA). International Journal of Humanities and Social Sciences, 3(7), 148154. Retrieved from http://www.waset.org/journals/ijhss/v3/v3-7-65.pdf

Bardagi, M. P., Lassance, M. C. P., \& Paradiso, A. C. (2003). Trajetória acadêmica e satisfação com a escolha profissional de universitários em meio de curso [University students' academic trajectory and satisfaction with career choice in the middle of the course]. Revista Brasileira de Orientação Profissional [online], 4(1/2), 153-166. Retrieved from http://pepsic.bvsalud. org/scielo.php?script=sci_arttext\&pid=S1679$33902003000100013 \& \operatorname{lng}=$ pt\&nrm=iso

Barros, R. P., \& Santos, E. C. (1996). Consequências de longo prazo do trabalho precoce [Long term consequences of precocious work]. In A. Fausto \& R. Cervini (Eds.), O trabalho e a rua: Crianças e adolescentes no Brasil urbano dos anos 80 (pp. 56-61). São Paulo, SP: Cortez.

Borges, C. C., \& Magalhães, A. S. (2009). Transição para a vida adulta: Autonomia e dependência na família [Transition to the adult life: autonomy and dependence]. Psico, 40(1), 42-49. Retrieved from http://revistaseletronicas.pucrs. br/ojs/index.php/revistapsico/article/viewFile/3993/4140

Brazilian Federal Council of Psychology. (2000). Resolução para pesquisa com seres humanos [Resolution for research with human beings]. Resolução n. 016/2000. Brasília, DF: Author.

Camarano, A. A. (2006). Transição para a vida adulta ou vida adulta em transição? [Transition to adulthood or adulthood in transition?]. Rio de Janeiro, RJ: Instituto de Pesquisa Econômica Aplicada.

Camarano, A. A., Mello, J. L., Pasinato, M. T., \& Kanso, S. (2004). Caminhos para a vida adulta: As múltiplas trajetórias dos jovens brasileiros [Paths in direction to adulthood: Brazilian youth's multiple trajectories]. Última Década [online], 21, 11-50. doi:10.4067/S071822362004000200002

Campos, H. R., \& Francischini, R. (2003). Trabalho infantil produtivo e desenvolvimento humano [Child productive labor and development]. Psicologia em Estudo, 8, 119-129. doi:10.1590/ S1413-73722003000100015.

Costello, A. B., \& Jason, W. O. (2005). Best practices in Exploratory Factor Analysis: Four recommendations for getting the most from your analysis. Practical Assessment, Research and Evaluation, 10 (1/9). Retrieved from http://pareonline.net/pdf/v10n7.pdf

Cronbach, L. J. (1951). Coefficient alpha and the internal structure of tests. Psychometrika, 16, 297 334. doi: $10.1007 / \mathrm{bf} 02310555$ 
Demuth, C., \& Keller, H. (2011). Culture, learning, and adult development. In C. Hoare (Ed.), Handbook of Adult Development and Learning [chapter 22]. Oxford, UK: Oxford University Press.

Erikson, E. H. (1950). Infância e sociedade [Childhood and society]. Rio de Janeiro, RJ: Zahar.

Erikson, E. H. (1968). Identidade: Juventude e crise [Identity: Youth and crises]. Rio de Janeiro, RJ: Zahar.

Facio, A., \& Micocci, F. (2003). Emerging adulthood in Argentina. New Directions for Child and Adolescent Development, 100, 21-31.

Facio, A., Resett, S., Micocci, F., \& Mistrorigo, C. (2007). Emerging adulthood in Argentina: An age of diversity and possibilities. Child Development Perspectives, 1, 115-118. doi:10.1111/ j.1750-8606.2007.00025.x

Fierro Arias, D., \& Moreno Hernandez, A. (2007). Emerging adulthood in Mexican and Spanish youth: Theories and realities. Journal of Adolescent Research, 22, 476-503. doi:10.1177/0743558407305774

Fuligni, A. J. (2007). Family obligation, college enrollment, and emerging adulthood in Asian and Latin American families. Child Development Perspectives, 1, 96-100. doi:10.1111/j.17508606.2007.00022.x

Guimarães, R. M., \& Romanelli, G. (2002). A inserção de adolescentes no mercado de trabalho através de uma ONG [The inclusion of adolescents of lower classes in the job market through an ONG]. Psicologia em Estudo, 7, 117-126. doi:10.1590/S1413-73722002000200014

Hayton, J. C., Allen, D. G., \& Scarpello, V. (2004). Factor retention decisions in exploratory factor analysis: A tutorial on parallel analysis. Organizational Research Methods, 7, 191-207. doi:10.1177/1094428104263675

Henriques, C. R., Jablonski, B., \& Feres-Carneiro, T. (2004). A "Geração Cangurú": Algumas questões sobre o prolongamento da convivência familiar ["Kangaroo generation": Some questions about the prolonging of family cohabiting]. Psico, 35(2), 195-205.

Horn, J. L. (1965). A rationale and test for estimating the number of factors in factor analysis. Psychometrika, 30, 179-185. doi:10.1007/ BF02289447
Macek, P., Bejcek, J., \& Vanickova, J. (2007). Contemporary Czech emerging adults: Generation growing up in the period of social changes. Journal of Adolescent Research, 22, 444-475. doi:10.1177/0743558407305417

Marques, M. E., Neves, M. de A., \& Carvalho, A. C., Neto (2002). Trabalho infantil: A infância roubada [Child labor: The stolen infancy]. Belo Horizonte, MG: Segrac.

National Health Council. (1996). Resolução $n$. 196/1996. Brasília, DF: Author.

Pochmann, M. (2009). O trabalho na crise econômica no Brasil: Primeiros sinais [Working during economic crises in Brazil: First signs]. Estudos Avançados [online], 23(66), 41-52. Retrieved from http://revistas.usp.br/eav/article/ view/10408/12118

Ramos, S. G., \& Lima, E. R. (1996). O secundarista e o processo de escolha da profissão [High school students and the process of choosing a profession]. Revista Brasileira de Estudos Pedagógicos, 185(77), 191-219. Retrieved from http:// rbep.inep.gov.br/index.php/RBEP/article/viewFile/260/262

Reifman, A., Arnett, J. J., \& Colwell, M. J. (2007). Emerging Adulthood: Theory, assessment and application. Journal of Youth Development, 2(1).

Sarti, C. A. (1996). A familia como espelho [The Family as a mirror]. São Paulo, SP: Autores Associados.

Sparta, M., Bardagi, M. P., \& Andrade, A. M. J. (2005). Exploração vocacional e informação profissional percebida em estudantes carentes [Vocational exploration and perceived career information in low-income students]. Aletheia [online], 22, 79-88. Retrieved from http://pepsic. bvsalud.org/pdf/aletheia/n22/n22a08.pdf

Veiga, A. (1998, July). Os boas-vidas [Les bon vivant]. Veja, 31(29), 80.

Yu, C. Y. (2002). Evaluating cutoff criteria of model fit indices for latent variable models with binary and continuous outcomes. Los Angeles, CA: University of California. 